\title{
Ectopic Cushing's syndrome caused by a pulmonary ACTH-secreting tumor in a patient treated with octreotide
}

\author{
Síndrome de Cushing ectópico causado por um tumor \\ pulmonar secretor de ACTH em tratamento com octreotide
}

Pedro Rodrigues ${ }^{1,2}$, José Luís Castedo', Margarida Damasceno³, Davide Carvalho ${ }^{1,2}$

\begin{abstract}
SUMMARY
Ectopic ACTH syndrome is a rare disease often associated with severe hypercortisolism. When feasible, optimal management is surgical excision of the tumor. A 33-year-old male patient was admitted to the hospital in 1993 with clinical manifestations suggestive of Cushing's syndrome. He presented high plasma ACTH and markedly elevated urinary free cortisol excretion that was not suppressed with high-dose dexamethasone administration. Pituitary MRI scan was normal. No central-to-peripheral ACTH gradient was present in bilateral inferior petrosal sinus sampling. Thoracic CT scan showed a $1.7 \mathrm{~cm}$ nodule at the left lung. Pulmonary fine needle cytology and immunocytochemical and ultrastructural studies, together with the presence of bone metastases, led to the diagnosis of an ACTH-producing neuroendocrine carcinoma. He was initially submitted to chemotherapy and has been on treatment with octreotide LAR since 1998, having shown a favorable clinical, biochemical and imaging response. We highlight the excellent longterm response to medical therapy with octreotide LAR, without tachyphylaxis, probably due to its antiproliferative effect. Arq Bras Endocrinol Metab. 2012;56(7):461-4
\end{abstract}

\section{SUMÁRIO}

A secreção ectópica de ACTH é uma síndrome rara associada habitualmente à hipercortisolemia grave. A remoção cirúrgica do tumor é o tratamento de primeira linha, sempre que seja exequível. Homem com 33 anos, internado em 1993 com manifestações clínicas sugestivas de síndrome de Cushing, apresentava valores elevados de ACTH plasmática e excreção urinária de cortisol livre muito aumentada, sem supressão na prova com dose alta de dexametasona; RM hipofisária sem alterações; cateterismo bilateral dos seios petrosos inferiores sem gradiente central-periférico de ACTH. A CT de tórax mostrou um nódulo de $1,7 \mathrm{~cm}$ no pulmão esquerdo. $\mathrm{O}$ diagnóstico de carcinoma neuroendócrino produtor de ACTH foi feito com base nos resultados citológico, imunocitoquímico e ultraestrutural, juntamente com a presença de metástases ósseas. Foi inicialmente submetido à quimioterapia e encontra-se em tratamento com octreotide LAR desde 1998, apresentando resposta clínica, bioquímica e imagiológica favorável. Destacamos a excelente resposta a longo prazo à terapêutica com octreotide LAR, sem taquifilaxia, provavelmente devido ao seu efeito antiproliferativo. Arq Bras Endocrinol Metab. 2012;56(7):461-4
Department of Endocrinology, Diabetes and Metabolism, Centro Hospitalar de São João EPE, Porto, Portugal 2 Porto Medical School, Portugal ${ }^{3}$ Department of Oncology, Centro Hospitalar de São João EPE, Porto, Portugal

\section{INTRODUCTION}

$\mathrm{E}$ ctopic adrenocorticotropic hormone (ACTH) secretion is responsible for $12 \%-17 \%$ of cases of Cushing's syndrome. It is a rare disease with a reported incidence of 0.1 per million per year. Various tumors can cause ectopic ACTH syndrome (EAS), particularly those originating from neuroendocrine cells $(1,2)$. Hypercortisolism is usually severe and of rapid onset. Metabolic changes like hypokalemia and metabolic al- kalosis are common (3). After biochemical confirmation of EAS, optimal management includes localization and removal of the ACTH ectopic source (4). Once the lesion has been located, optimal treatment is surgical excision of the tumor (1). Prognosis is mainly determined by primary tumor histology. Although advances in medical and surgical treatments have improved the overall survival rate of these patients, most cases have poor prognosis (5). 


\section{CASE REPORT}

A 33-year-old male patient presented in 1991 with temporal headaches, generalized fatigue, muscle weakness, and gradual facial edema. Hypertension was diagnosed in June 1993 and he was admitted to the hospital six months later. Physical examination revealed central obesity, plethoric facies, buffalo hump, skin hyperpigmentation, wide and red abdominal and axilar striae, mild atrophy of the proximal muscles of lower limbs, and a blood pressure of $170 / 100 \mathrm{mmHg}$.

Laboratory assays showed high plasma ACTH (193.4 $\mathrm{pg} / \mathrm{mL}$ at 8:00 am; $203.1 \mathrm{pg} / \mathrm{mL}$ at 4:00 pm; reference range: $9-52)$ with normal serum cortisol (20.7 $\mu \mathrm{g} / \mathrm{dL}$ at 8:00 am; $22.5 \mu \mathrm{g} / \mathrm{dL}$ at 4:00 $\mathrm{pm}$; reference range: 8-28) but markedly elevated 24-h urinary free cortisol excretion (1216.0 $\mu \mathrm{g}$ per day; reference range: 35.0-120.0). Low-dose and high-dose dexamethasone suppression tests were performed with no suppression of serum cortisol or urinary free cortisol. No glucose intolerance, hypokalemia or hypocalcemia were present.

Pituitary magnetic resonance imaging (MRI) showed no direct or indirect signs of the presence of tumors. No central-to-peripheral ACTH gradient was observed in bilateral inferior petrosal sinus sampling (BIPSS). Plain chest X-ray showed a $1.5 \mathrm{~cm}$ nodular image in the left lung. The patient was submitted to bronchoscopy but no morphologic or topographic lesions were visualized in the tracheobronchial tree. Cytological examination of bronchoalveolar lavage was negative for malignancy. Thoracoabdominal computed tomography (CT) scans revealed a well-delimited 1.7 $\mathrm{cm}$ nodule in the anterior segment of the superior left lung lobe, compatible with neoplasm. Adrenal glands were normal. Bone scan revealed metastases located in the skull, ribs, lumbar spine and sacrum. Lung fine-needle cytology and immunocytochemical and ultrastructural studies (Figure 1) were compatible with a neuroendocrine tumor. At that time, due to the presence of bone metastases, the patient was diagnosed with EAS caused by an ACTH-producing neuroendocrine lung carcinoma. Bone biopsy was not performed to confirm the radiologic interpretation of the lesions.

He was treated with ketoconazole $(200 \mathrm{mg}$ twice daily), anti-hypertensive drugs and, in April 1994, started chemotherapy with cyclophosphamide, carboplatin, and etoposide. One year after diagnosis he had no muscle weakness complaints, less central obesity, less conspicuous red striae and normal blood pressure, al- though under anti-hypertensive therapy. Urinary free cortisol excretion normalized (15.4 $\mu$ g per day) but plasma ACTH remained elevated $(218.9 \mathrm{pg} / \mathrm{mL}$ at 8:00 am; $236.4 \mathrm{pg} / \mathrm{mL}$ at 4:00 pm). Follow-up thoracic CT scan did not show enlargement of the nodule.

An ${ }^{111}$ In-octreotide scan performed in September 1995 showed radiotracer enhancement of the lung nodule but no bone lesions were observed. Three months later, the patient began subcutaneous octreotide $(100 \mu \mathrm{g}$ three times a day). A bone scan performed in 1997 showed images compatible with metastases located in the ribs, thoracic spine, left iliac bone, and left femur. In 1998 he started treatment with intramuscular octreotide long-acting release (LAR) $20 \mathrm{mg}$ once a month. Bone scan performed in 2000 described radiotracer enhancement foci located in the posterior region of several ribs, but no evidence of the previously described lesions.

Regular follow-up examinations have been performed with clinical, laboratory and imaging surveillance. He had progressive resolution of Cushing's clinical features and blood pressure normalization without any anti-hypertensive drug since 2001. A thoracoabdominal CT scan performed in December 2007 showed persistence of a $13-\mathrm{mm}$ nodule in the superior left lung lobe, and one $15-\mathrm{mm}$ hepatic nodule that was not seen in previous scans (Figure 2). Hepatic MRI performed in January 2008 revealed a $15-\mathrm{mm}$ nodular lesion suggestive of metastasis (Figure 3). An ${ }^{111}$ In-octreotide scan done two months later showed a single enhanced focus corresponding to the lung lesion, and no other images suggestive of secondary lesions, namely in the hepatic parenchyma. A ${ }^{68} \mathrm{Ga}$-DOTANOC PET/CT scan performed in October 2008 also showed radiotracer enhancement only in the lung nodule, without other foci suggestive of lesions with somatostatin receptors expression. A Tc ${ }^{99} \mathrm{~m}$-labeled red blood cell scintigraphy performed in January 2009 did not show images

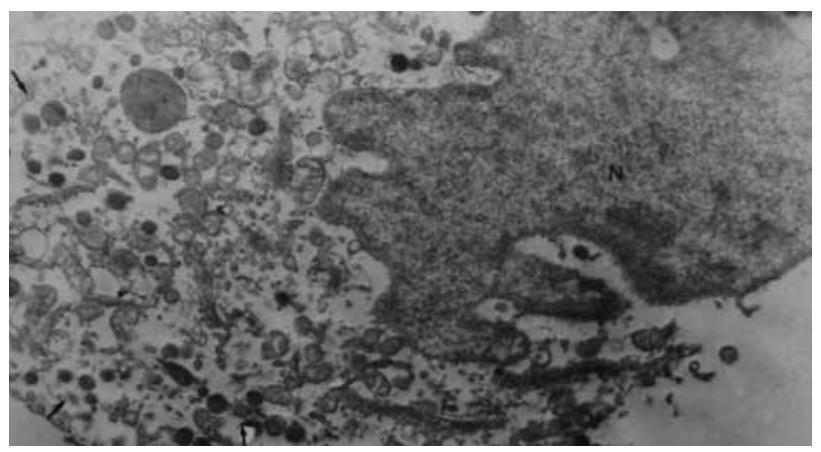

Figure 1. Ultrastructural photomicrograph showing neuroendocrine granules (x 8000). 

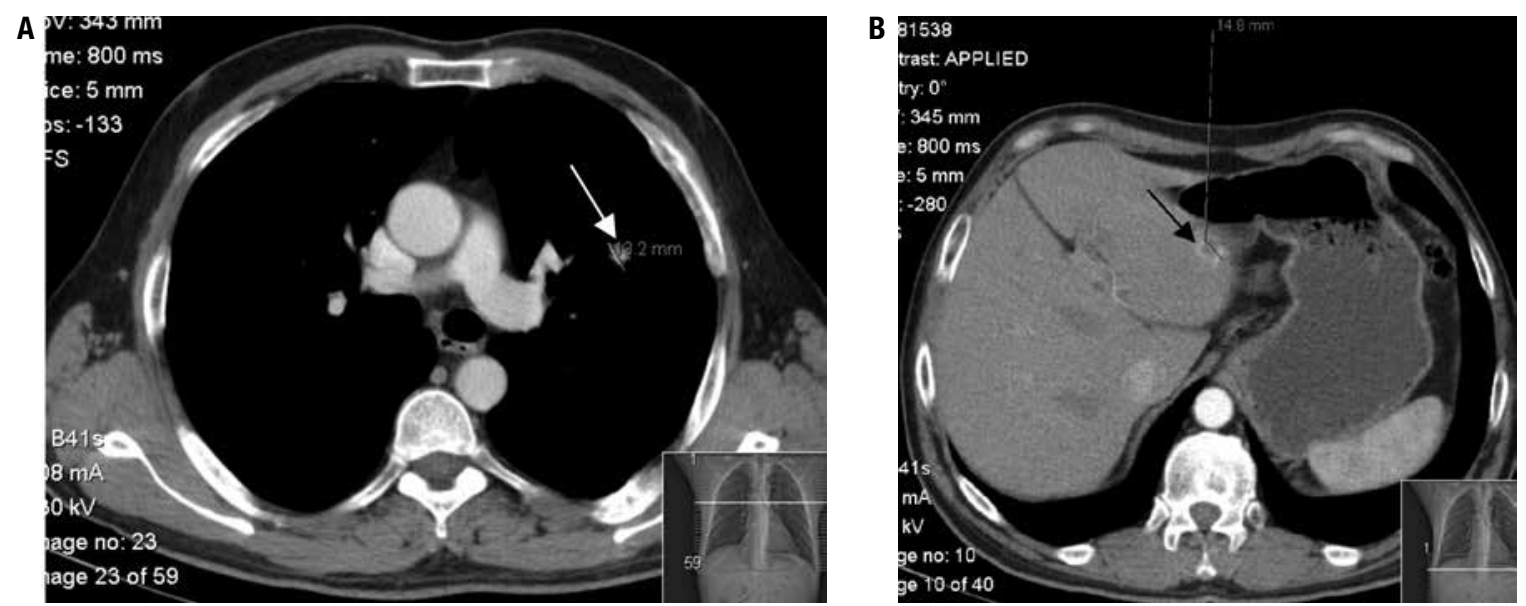

Figure 2. Thoracoabdominal CT scans. Figure $2 \mathrm{~A}$ shows a $13.2 \mathrm{~mm}$ nodule in the superior left lung lobe (arrow) and figure $2 \mathrm{~B}$ shows a $14.8 \mathrm{~mm}$ nodule in the hepatic parenchyma (arrow).

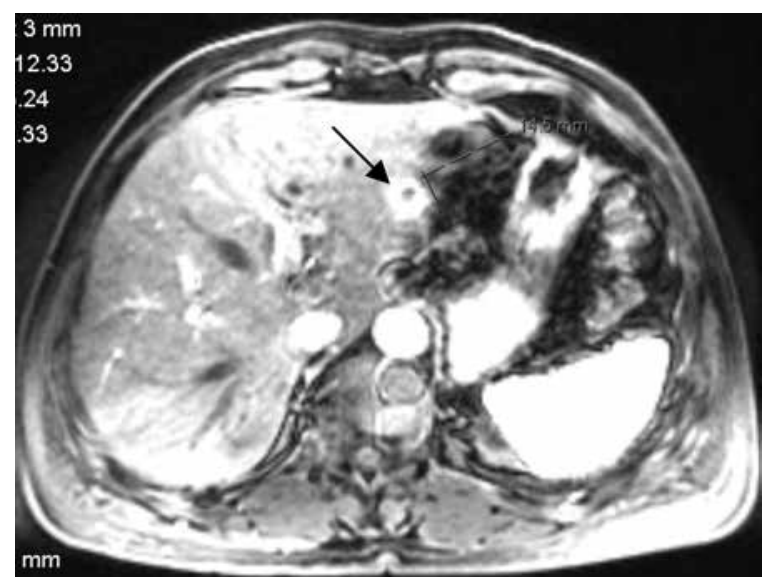

Figure 3. Hepatic MRI showing a nodular lesion suggestive of metastasis (arrow).

of hepatic hyperactivity compatible with hemangioma. The case was discussed on a Neuroendocrine Tumors Reunion Group which decided to maintain treatment with octreotide LAR and to perform periodic surveillance. Biopsy of the hepatic nodule was not performed.

The patient is now 54 years-old and has no clinical or biochemical evidence of recurrence. Last laboratory assays (January 2012) showed normal values for plasma ACTH $(43.2 \mathrm{pg} / \mathrm{mL}$ at $8: 00 \mathrm{am} ; 29.0 \mathrm{pg} / \mathrm{mL}$ at $4: 00$ $\mathrm{pm})$, serum cortisol ( $12.8 \mu \mathrm{g} / \mathrm{dL}$ at $8: 00 \mathrm{am} ; 6.9 \mu \mathrm{g} / \mathrm{dL}$ at 4:00 pm) and 24-h urinary free cortisol (30.8 $\mu \mathrm{g}$ per day). A bone scan performed in December 2011 showed discrete radiotracer enhancement only in the posterior region of several ribs, suggestive of old post-traumatic sequelae. Last thoracoabdominal CT scan done in February 2012 revealed no enlargement of the lung nodule and no dimensional or morphologic changes concerning the hepatic nodular lesion. Last ${ }^{111}$ In-octreotide scan performed also in February 2012 showed persistence of a small enhanced nodule in the left lung parenchyma and no images suggestive of secondary lesions.

\section{DISCUSSION}

We present a case of EAS caused by an ACTH-producing neuroendocrine lung tumor. The ectopic source of ACTH is located in the lungs in over $45 \%$ of tumors. Most cases (> 25\%) are bronchial carcinoid tumors $(6,7)$. Small cell lung carcinomas are responsible for about $20 \%$ of cases, although ectopic ACTH hypersecretion occurs in only $0.5 \%-2 \%$ of these tumors (3). Thymus $(11 \%)$ and pancreas $(8 \%)$ are the next most common organs that can harbor tumors causing EAS. Other sources, mostly related to tumors with neuroendocrine differentiation, include medullary thyroid carcinoma $(6 \%)$ and pheochromocytoma $(5 \%)$. The most recently published series conclude that two thirds of tumors are located in the thorax, neck, or adrenal glands, and that only one third is found in other intra-abdominal organs (8). Patients with EAS can present extremely high circulating ACTH concentrations and cortisol secretion rates. Metabolic manifestations of glucocorticoid excess are often rapid and progressive (9). Hypokalemia is present in about $70 \%$ of cases and is related with the degree of hypercortisolemia $(10,11)$. In our patient, clinical features of hypercortisolism were present for about two years before diagnosis was established. No glucose intolerance or hypokalemic alkalosis were seen.

Diagnosing EAS is often difficult. None of the dynamic biochemical tests achieves 100\% accuracy, although BIPSS almost always shows absent central-toperipheral gradient (12). Patients with EAS tend to have higher ACTH levels than those with Cushing's disease, but there is no clear distinction between the 
two. BIPSS is considered the gold standard for differential diagnosis (1). In our case, dynamic biochemical tests and BIPSS suggested EAS.

Early detection of tumors causing EAS is important to avoid bilateral adrenalectomy and to reduce the risk of metastatic disease (4). Once suspected, the best approach to localize the source of ectopic ACTH is by means of high-resolution, thin-section contrast-enhanced imaging using either CT or MRI (1). In our patient, a lung nodule was first detected by a plain chest X-ray that was further confirmed using CT imaging. Cytological, immunocytochemical and ultrastructural studies, together with the presence of bone metastases, led to the diagnosis of an ACTH-producing neuroendocrine carcinoma.

The first line treatment of EAS is surgical excision of the tumor. This can be achieved with curative intent in up to $40 \%$ of patients and is associated with complete remission in more than $80 \%$ of cases (5). After diagnosing EAS in our patient, surgical resection was not performed since he presented bone metastases presumably due to spread of the lung tumor. He was first submitted to chemotherapy and since 1998 has been on treatment with octreotide LAR. Nineteen years after diagnosis the patient maintains excellent response to medical therapy with octreotide LAR, without tachyphylaxis.

Some studies have reported notable antitumor effects of the somatostatin analog octreotide LAR in neuroendocrine tumors. The PROMID study was designed to investigate its antiproliferative efficacy in patients with metastatic neuroendocrine tumors of the midgut (13). The investigators reported that octreotide LAR significantly increased the median time to tumor progression compared with the placebo (14). These findings support an antiproliferative effect of octreotide LAR in patients with well-differentiated neuroendocrine tumors and low tumor burden, previously described in other studies (15). Stabilization of tumor growth, rather than tumor shrinkage, is the most frequent response to treatment $(16,17)$. Presumptive diagnosis of a neuroendocrine carcinoma was made by cytological analysis, due to the presence of bone lesions suggestive of metastases. Our patient did not have a midgut, but a lung neuroendocrine tumor; the Ki-67 index for proliferative growth was not determined and histological lung, and bone examinations were not performed. We assume that the patient has a well-differentiated, slow-growing tumor and that stabilization of the lesion over these years resulted from the antiproliferative effect of octreotide LAR. Nowadays, the patient feels well and does not want to be submitted to surgery.
Disclosure: no potential conflict of interest relevant to this article was reported.

\section{REFERENCES}

1. Isidori AM, Lenzi A. Ectopic ACTH syndrome. Arq Bras Endocrinol Metab. 2007;51(8):1217-25.

2. Baylin SB, Mendelsohn G. Ectopic hormone production by tumors: mechanisms involved and the biological and clinical implications. Endocr Rev. 1980;15:752-87.

3. Aron DC, Findling JW, Tyrrell JB. Glucocorticoids and adrenal androgens. In: Gardner DG, Shoback D, editors. Greenspan's Basic and Clinical Endocrinology. $8^{\text {th }}$ ed. New York: McGraw Hill; 2007. p. 346-95.

4. Newell-Price J, Trainer P, Besser M, Grossman A. The diagnosis and differential diagnosis of Cushing's syndrome and pseudoCushing's states. Endocr Rev. 1998;19(5):647-72.

5. Isidori AM, Kaltsas GA, Pozza C, Frajese V, Newell-Price J, Reznek $\mathrm{RH}$, et al. The ectopic adrenocorticotropin syndrome: clinical features, diagnosis, management and long-term follow-up. J Clin Endocrinol Metab. 2006;91(2):371-7.

6. Scanagatta P, Montresor E, Pergher S, Mainente M, Bonadiman C, Benato $\mathrm{C}$, et al. Cushing's syndrome induced by bronchopulmonary carcinoid tumours: a review of 98 cases and our experience of two cases. Chir Ital. 2004;56(1):63-70.

7. Ejaz S, Vissilopoulou-Sellin R, Busaidy NL, Hu MI, Waguespack SG, Jimenez C, et al. Cushing syndrome secondary to ectopic adrenocorticotropic hormone secretion: the University of Texas MD Andersen Cancer Center Experience. Cancer. 2011;117(19):4381-9.

8. Ilias I,Torpy DJ, Pacak N, Mullen N, Wesley RA, Nieman LK. Cushing's syndrome due to ectopic corticotropin secretion: twenty years' experience at the National Institutes of Health. J Clin Endocrinol Metab. 2005;90(8):4955-62.

9. Stewart PM. Adrenal cortex and endocrine hypertension. In: Kronenberg HM, Melmed S, Polonsky KS, Larsen PR, editors. Williams Textbook of Endocrinology. $11^{\text {th }}$ ed. Philadelphia, PA: WB Saunders; 2008. p. 445-537.

10. Beuschlein F, Hammer GD. Ectopic pro-opiomelanocortin syndrome. Endocrinol Metab Clin. 2002;31:191-234.

11. Torpy DJ, Mullen N, Ilias I, Nieman LK. Association of hypertension and hypokalemia with Cushing's syndrome caused by ectopic ACTH secretion: a series of 58 cases. Ann NY Acad Sci. 2002;970:134-44.

12. Fasshauer $M$, Lincke $T$, Witzigmann $H$, Kluge $R$, Tannapfel $A$, Moche $M$, et al. Ectopic Cushing's syndrome caused by a neuroendocrine carcinoma of the mesentery. BMC Cancer. 2006;6:108.

13. Öberg K. Cancer: antitumor effects of octreotide LAR, a somatostatin analog. Nat Rev Endocrinol. 2010;6(4):188-9.

14. Rinke A, Müller HH, Schade-Brittinger C, Klose KJ, Barth P, Wied $\mathrm{M}$, et al. Placebo-controlled, double-blind, prospective, randomized study on the effect of octreotide LAR in the control of tumor growth in patients with metastatic neuroendocrine midgut tumors: a report from the PROMID Study Group. J Clin Oncol. 2009;27(28):4656-63.

15. Rindi G, Klöppel G, Couvelard A, Komminoth P, Körner M, Lopes $J M$, et al. TNM staging of midgut and hindgut (neuro) endocrine tumors: a consensus proposal including a grading system. Virchows Arch. 2007;451(4):757-62.

16. Susini $C$, Buscail $L$. Rationale for the use of somatostatin analogs as antitumor agents. Ann Oncol. 2006;17(12):1733-42.

17. Öberg K, Kvols L, Caplin M, Delle Fave G, de HerderW, Rindi G, et al. Consensus report on the use of somatostatin analogs for the management of neuroendocrine tumors of the gastroenteropancreatic system. Ann Oncol. 2004;15(6):966-73. 